\title{
Literatura de la guerra civil: la niñez como espejo hermenéutico para la comprensión histórica
}

\author{
Civil war literature: childhood as a hermeneutical \\ mirror for historical understanding
}

Biagio Grillo ${ }^{1}$

Fecha de recepción: 12 de octubre de 2020

Fecha de aceptación: 26 de diciembre de 2020 


\section{Resumen}

Frente a la guerra civil como acontecimiento abierto a la significación del presente, la figura del niño es convocada por la literatura (a partir del siglo XX) en un diálogo que complementa la hermenéutica de la historiografía. Autores como Nellie Campobello, Italo Calvino y Aurora Correa sitúan la clave epistémica de la narración en un niño o en una niña que, desde su peculiar subjetividad marginal, construyen una significación del clima histórico marcada por distanciamiento $y$ en contraste con la narrativa oficial. Así, la voz y el testimonio de estos niños no se limita a lo verosímil: destaca la esencia histórica, vivencial y emocional del acontecimiento "guerra civil". En un análisis comparativo histórico-literario, en este artículo se examina la construcción de la "voz" y del proceso de enunciación protagonizado por la figura ficcional del niño como ejercicio reflexivo sobre el fenómeno en su dimensión compleja, humana y plural.

Palabras clave: niñez; discurso; literatura; guerra civil, historia cultural.

\section{Abstract}

In the civil war literature, the war is treated as an event open to the significance of the present. Furthermore, in many of these texts, the figure of the child is summoned (from the 20th century) in a dialogue that complements the hermeneutics of historiography. Authors such as Nellie Campobello, Italo Calvino, and Aurora Correa place the epistemic key of the narration in a child from its peculiar marginal subjectivity, building a signification of the historical context marked by distancing, contrasting the official narrative. Therefore, the voice and testimony are not limited to the plausible: the historical essence is prominent, experiential, and emotional of the "civil war" event. In this research, a comparative historic-literary study is presented, analyzing the creation of the "voice" and the enunciation process lead by the fictional figure of a child as a reflexive exercise in its complex, human, and plural dimensions.

Keywords: childhood; speech; literature; civil war; cultural history. 


\section{Introducción}

E 1 niño, como sujeto, nos aparece irremediablemente distante. Aunque inteligible, su voz extraña y desconcierta por la aparente autorreferencialidad de su mundo. Por un lado, es una voz que nos trasmite nostalgia y una inocencia "mítica" (como la del "buen salvaje"). Por otro lado, sin embargo, censura, pospone y aleja una multiplicidad de discursos (y de otras voces) porque se considera no apropiada, como cualquier discurso de la guerra y sobre la guerra. Así, frente a la alteridad de su voz, pareciéramos quedar atrapados en ese hechizo de los antiguos romanos, en su "lupus in fabula": la presencia o aparición del niño, como la del lobo, parece condenar a la pérdida del habla. En cambio, el siglo XX muestra la superación paulatina de esta afasia y el niño empieza a aparecer en la pluralidad de discursos: puer in fabula ${ }^{2}$ Como sujeto, el niño es entonces redescubierto tras la nueva sensibilidad y visión posfreudiana que en este siglo se afirma. Además, esta nueva sensibilidad se traducirá, jurídicamente, en la Declaración de Ginebra sobre los Derechos del niño (1924).

En diferentes momentos de la contemporaneidad, a partir del siglo XX, Nellie Campobello, Italo Calvino y Aurora Correa colocan a un niño o a una niña en el centro de su propio discurso (literario, pero también histórico y autobiográfico) para narrar sus respectivas guerras civiles. Así, recuperado de la tradición popular y de la fábula, el niño se vuelve ahora sujeto en un marco espacial y temporal problemático, en un sentido histórico y sociocultural (a veces entremezclado con atmósferas al límite de lo fantástico). Pareciera, entonces, que la producción narrativa occidental encuentra en la figura del niño una nueva subjetividad y un nuevo potencial para contar historias: en su "inocencia”, el niño es caracterizado como el depositario de un punto de vista amoral y objetivante de la "realidad".

Más allá de la voluntad de describir la infancia, el niño aporta en la Literatura (como en el cine) una mirada crítica sobre la "realidad" antes desconocida. En este sentido, es evidente el carácter innovador de una novela como Cartucho, publicada ya en 1931. De ella, en el "Prólogo" a Mis libros, la autora escribe:

Busqué la forma de poder decir, pero para hacerla necesitaba una voz, y fui hacia ella. Era la única que podía dar el tono, la única autorizada: era la voz de mi niñez. Usar de su aparente inconsciencia para exponer lo que supe era la necesidad de un decir sincero y directo. (Campobello, 2017, p. 343)

Esta "aparente inconsciencia" autoriza un punto de vista crítico y alternativo sobre el acontecimiento, el cual -como en la célebre fábula de Andersen- puede declarar una "verdad" (subjetiva, pero factual) que en caso contrario quedaría negada al escritor. Así, Campobello, Calvino y Correa construyen un acto de comunicación y expresión en la figura del niño, dotándolo de una forma verbal y fónica "para introducir en el mensaje el signo de una presencia deseante" (Filinich, 2013, p. 208). Este "mensaje" en sus respectivas novelas -Cartucho: Relatos de la lucha en el Norte de México (1940), El sendero de los nidos de araña (1947) y Cerezas (2008)- construye una significación plural y compleja de la guerra civil como

2- Importantes precursores del uso contemporáneo de la figura del niño pueden considerarse, en mi opinión, Charles Dickens (1812- 1870) y Lewis Carroll (1832-1898). En novelas como Oliver Twist (1838), Dickens da protagonismo al niño en la perspectiva de un realismo social que busca delatar la injusticia de la nueva modernidad industrial. Por otro lado, la Alicia de Carroll (1865) parece marcar un paso más hacia la que será la concepción contemporánea de la niñez: Alicia ya no es simplemente objeto de una mirada adulta que la retrata como víctima, sino el sujeto de una realidad cuya significación se desborda de la surrealidad del mundo de las maravillas. Este último aspecto adquirirá siempre mayor evidencia en la transición al siglo XX, con el niño que juega en la narrativa una función predicativa y se vuelve instrumento de una mirada crítica y objetivante de la realidad social e histórica como "memoria ejemplar" (Todorov, 2000). 
acontecimiento, es decir, como evento histórico "abierto" en el presente de la memoria y de la enunciación, como parteaguas que marca en la materialidad del tiempo un antes y un después (Guillén, 1985; Koselleck y Gadamer, 1997).

La voz de estos niños ficcionales no está desvinculada de la Historia (como historia del evento y como palabras de esa historia). Pero su narrativa no tiene la rígida coherencia ni la linealidad que la interpretación histórica cientificista desea: novelas dialógicas, diría Bajtín (1989), contra discursos monológicos. Por lo tanto, en la niña que dice "yo" en Cartucho, en Pin y en Aurora-niña, hay un discurso que -aunque se funda en la enunciación de un sujeto infantil- no simplifica, sino que rechaza la simplificación. A partir de estos "registros de palabras" (Todorov, 1971, p. 99), se abre entonces un diálogo complejo de voces y significaciones al cual es llamado, de manera virtual, el mismo lector como voz potencial frente a la complejidad de un acontecimiento problemático como lo es la guerra civil.

Este artículo analiza la figura del niño en tres novelas histórico-testimoniales de la guerra civil, es decir, en la yuxtaposición simbólica de la llamada Revolución mexicana (en su fase civil, 1913-1920), de la Guerra civil española (1936-1939) y de la Guerra partisana o Resistencia italiana (1943-1945). Se trata, entonces, de un referente espacial y temporal no contiguo, pero interconectado en una perspectiva temática al ser el objeto de la mirada ficcional y narrativamente construida de un observador infantil. Estos niños:

i) Como personajes-testigos, viven el evento desde su alteridad y desde su peculiar punto de vista;

ii) Traducen en literatura una experiencia biográfica directa de los autores de las novelas en el escenario trágico de la guerra civil.

Acorde con lo anterior, el siguiente análisis comparativo e interdisciplinario muestra cómo -a partir del siglo XX- la figura protagónica del niño puede hacerse cargo del proceso de enunciación (como actor en diálogo/conflicto con una red preexistente de discursos) y de la autoridad de una "voz" (como elemento textual que informa sobre las significaciones y las emociones del sujeto) para abrir un puente hermenéutico de comprensión del referente histórico complejo. Asimismo, gracias al distanciamiento de la voz infantil, las tres novelas se vuelven una fuente complementaria para la historia, porque su narración atestigua lo que María Malatesta (2005) define como el "aura" del evento histórico y cumple con la necesidad humana de "ver" para conocer y comprender (Pitocco, 2013). Entonces, la elección de la voz infantil no parece un recurso casual. De esta forma, la literatura puede aportar al discurso histórico y a la reconstrucción de una significación desde la subjetividad (aunque ficcional) de sus testigos: en su conjunto, los diferentes puntos de vista infantiles conforman una mirada plural, con una tendencia estereoscópica, sobre un mismo fenómeno complejo.

\section{Cartucho: la Revolución de la niña que dice "yo" y su voz}

Había una vez una niña, una niña en la Revolución. No era una niña-soldadera con la canana cruzada en la espalda, ni con un rifle cargado en las manos. Era una niña del montón, en la calle Segunda del Rayo, en Hidalgo del Parral, en el norte de aquel país que el náhuatl ubicaba "en el ombligo de la 
luna”. Esa niña narra, como testigo y en primera persona, los sucesos del conflicto y protagoniza la novela Cartucho. Relatos de la lucha en el norte de México. La novela es publicada en 1931 por Nellie Campobello (1900-1986) para la editorial Ediciones Integrales y alcanza su forma definitiva en $1940^{3}$, cuando la editorial EDIPSA publica su segunda edición ampliada y corregida con 56 capítulos, bajo la supervisión de Martín Luis Guzmán. Esa niña nunca dice su nombre. Podríamos, tal vez, llamarla Francisca, Xica o -inclusive- Nellie. Pero esto sería un error: esa niña es una ficción sin nombre. Y, en ausencia de un nombre propio, puede tener todos aquellos nombres que se perdieron en la tolvanera de la guerra y de la historia. No dice su nombre, igual que Cartucho, el personaje epónimo de la novela. Pero, a diferencia de éste, ella no desaparece, sino que perdura, protagónica, como foco de la narración. Esa niña es la sinestesia de las miradas lanzada sobre la barbarie cotidiana en los tiempos de la Revolución y sobre la retórica de ese presente ya convertido en ayer. Compañera de juegos de la Parca, la niña sin nombre mira, observa y despide, con palabras leves y oníricas, a los muertos. Todo lo visto permanece así en la retina de una niña de ficción y se fija, para la posteridad, en las páginas escritas de la novela.

En Cartucho, el escenario principal es la calle Segunda del Rayo y allí la niña se ubica al centro de éste, en el número 21. Según la descripción de Irene Matthews, ésta era una calle "larga, estrecha, torcida, con pendientes y un viejo puente de piedra que cruza el río" y "se situaba en un barrio modesto, donde vivían familias de obreros, también había cantinas, músicos, «muchas risueñas» y cuarteles de soldados" (1997, p. 31). Es un escenario popular que las circunstancias de la guerra, en un cambio de focalización, hacen principalmente femenino con la historia que irrumpe con fuerza y violencia adentro de los hogares (Portelli, 2019). Es desde aquí que la niña observa, como espectadora interesada, la guerra. No va hacia ésta, no abraza las armas, sólo la observa invadir su mundo, su hogar y su infancia. Como niña, es decir, como "mujer en miniatura", cumple con el papel social y de género que el principio de siglo XX dicta: se ubica dentro del hogar, cuida la casa y a sus hermanos menores. Sin embargo, su voz subvierte ese papel frente al conflicto de los hombres, revelando el protagonismo femenino de una comunidad "otra" que, del mismo modo, vive y lucha en los márgenes. Su voz, además, desde su yo, señala las condiciones y las circunstancias de su enunciación frente al referente, como su relación con lo narrado y la dimensión emocional y humana de la experiencia.

Entre los balazos que "cosen" narrativamente epitafios e impresiones de los hombres del Norte, la niña configura entonces una narración intradiegética. En este papel, su voz prioriza el valor testimonial como aportación a la significación del pasado, como heterodoxia de una narración que radica en la experiencia directa, ocular, pero también en la experiencia de otros, de terceras personas involucradas en una visión plural. Así, a veces, la verbalización es delegada y la voz es cedida momentáneamente a un personaje cercano a la niña, ya sea un vecino o un familiar que narra "como si fuera un cuento" (Campobello, 2017, p. 131). En este yo ficcional confluyen otras vivencias y otros canales cognoscitivos: como recuerda Elizabeth Jelin (2002), la memoria requiere siempre una construcción dialógica.

Con su nariz pecosa metida en todo lo que acontece a su alrededor, la niña está presente para enunciar. Deja escuchar su voz, en una enunciación epistémicamente modalizada que compromete a la niñanarradora con la verdad de su relato. Sin embargo, de manera constante, es subrayada su "inevitable" 
parcialidad. Es parcial no porque sea ficcional y por ende ficticia, sino por la ontología situada de toda verdad y todo testimonio. También, es parcial porque es una verdad que se afirma en la voz de una niña, de una no-civis, y por esta razón potencialmente desfasada o distante respecto a una visión adulta y oficialista. En este sentido, la voz recuerda con frecuencia la naturaleza infantil de su mente y de su mirada: como cuando nota, en el cadáver del Coronel Bufanda, la herida mortal de una bala en coincidencia del corazón y de la bolsa del chaquetín, y así sus ojos, "orientándose en la voz del cañón", definen la bolsa "desgarrada como una rosa” (Campobello, 2017, p. 114). Otras veces, la enunciación pasa por predicados no factivos con el objetivo de reafirmar la niñez de la voz: "Yo pensé que sería un general como casi todos los villistas" (p. 127). Sin embargo, no faltan pasajes del texto que certifican de forma asertiva el valor de verdad de lo dicho, sobre todo frente a la "injuria" del villismo ${ }^{4}$ (Carballo, 1994). En estos casos pareciera superponerse una presencia textual de la autora a la voz de la niña-narradora: como cuando reescribe el final de Nacha Cenicero, afirmando: "Ahora digo, y lo digo con la voz del que ha podido destejer una mentira" (Campobello, 2017, p. 111).

De esta forma, a través de las proposiciones que conforman los 52 capítulos-fragmentos, la niña es el trámite que permite el conocimiento dirigido a un narratario que no es explícito en la novela y se deja entrever sólo en la "sobrejustificación" (Prince cit. en Filinich, 2013) de un discurso impreciso y a veces limitado por el paso del tiempo, por obstáculos físicos o por la misma alteridad del sujeto. Pero se trata de una narración que, en el proceso de enunciación, muestra consciencia del papel de la voz narradora, como cuando manifiesta estrategias de elipsis con la finalidad de evitar el riesgo de no ser creída: "No quiero decir lo que le vi hacer ni lo que decía, porque parecerá exagerado" (Campobello, 2017, p. 120). Estas estrategias reflexivas de enunciación ratifican lo que ya la condición infantil del sujeto-narrador entraña, es decir, su veracidad o por lo menos su (proverbial) sinceridad, pero al mismo tiempo -siguiendo a Todorov- abren "una vía vertiginosa a la creación de sentidos nuevos $y$, por cuidadoso que se sea en sus descripciones sucesivas, una parte de este sentido queda siempre fuera de nuestro alcance" (1971, p. 39). El acto narrativo subraya una primera persona e introduce un testimonio que es situado porque es subjetivo -aunque en diálogo con una memoria colectiva que declaradamente lo revalida- y a esta subjetividad confía el potencial cuestionamiento de la verdad oficial: "Digo exactamente lo que más se me quedó grabado, no acordándome de palabras raras, nombres que yo no comprendi”" (Campobello, 2017, p. 127).

La voz de la niña abre varios fragmentos con la introducción de un nuevo personaje, un héroe-soldado cuya presencia se revelará efímera en el breve arco del capítulo mismo. Vemos, por ejemplo, el fragmento "Mugre": "José Díaz es el muchacho más bello que conozco, elegante, distinguido, me prometió venir a tomar café -dijo una hermana de papá" (Campobello, 2017, p. 117). En primer lugar, el personaje es descrito en su aspecto físico. En el caso de José Díaz la descripción es rápida y concisa ("bello", "elegante, distinguido"). En otros casos, la descripción abunda de adjetivos y particulares. Sigue la descripción fáctica, con énfasis en la relación que el personaje tiene con la niña protagonista. Esta relación puede ser directa, indirecta (mediada por la presencia de la madre o de un tercer personaje) o -como en este caso- filtrada por la imaginación lúdica de la niña:

4- Nellie Campobello habla de "injuria" al referirse a la proscripción que el villismo subió en la época del Maximato (19281934): la narrativa histórica oficial de la Revolución institucionalizada excluía a Villa, como "Atila del Norte" y lo volvía depositario de todos los excesos revolucionarios (Avechuco, 2017). 
El bello José Díaz estaba platicando. Dije tres veces: “Sí, voy a hacerlo novio de Pitaflorida, mi muñeca princesa; le haré un vestido azul y le pondré estrellas de "de veras" de las que vende don Luis el varillero”... . Un día le contó a Toña que él odiaba el sol, por su cara y sus manos. A ella le parecía muy bien y a mí (que me decían "solera”) me pareció mucho muy bien, por Pitaflorida; yo nunca hubiera casado a mi princesa con un hombre prieto. (p. 117)

El juego y la especificidad del habla confirman la dimensión infantil de la relación y cristalizan un contexto doméstico como espacio familiar y ajeno al campo de batalla, justo antes del ordinario "giro" narrativo que sanciona el reaparecer de la realidad bélica. Se trata de un giro brusco que puede alternar en el breve espacio de dos líneas el mundo del juego y el mundo de la guerra sin continuidad lógica. De la muñeca, por ejemplo, a las balaceras oídas desde el cerro:

A veces él se reía al ver la casa, Pitaflorida no se reía.

Hubo un combate de siete horas, los villistas dentro. El combate era zumbido; una caballería se fue por el cerro de los Aburridos derecho al rancho Rubio. (pp. 117-118)

El cambio brusco, aunque no anticipado narrativamente, es ordinario en el ritmo del texto y en la sucesión de los fragmentos. A la secuencia bélica le sigue un cierre melancólico y poético que concluye el círculo narrativo y cuenta los efectos mortíferos e irónicos del combate:

No, no, él nunca fue el novio de Pitaflorida, mi muñeca, que se rompió la cabeza cuando se cayó de la ventana, ella nunca se rió con él.

José Díaz, joven hermoso, murió devorado por la mugre; los balazos que tenía se los dieron para que no odiara al sol. (p. 118)

En esta oposición mugre-sol y con la retórica de un efecto de extrañamiento, el cierre subraya la distancia entre mundos diferentes que conviven y se alternan sobre la página y en los escenarios contiguos de la aldea. Por un lado, el espacio inhumano del cerro, de las balas y de la mugre; por el otro, el espacio doméstico y humano de la casa, del café y de la charla: por un lado, lo masculino que en sus diferentes avatares da y recibe muerte, por el otro, lo femenino de la niña y de la madre que asiste a la muerte y de los muertos tiene la cuenta.

Es la madre, a veces, quien decreta la irreversibilidad de la presencia de la guerra. Como se puede observar en el fragmento "El ahorcado", la violencia irrumpe, una vez más, sin estruendo en una narración que bajo la mirada infantil de la niña es presentada como ordinaria. La mirada adulta, por otro lado, no siempre queda impasible, dejando entrever un hiato y una disonancia en la linealidad del tiempo narrativo:

El del caballo estaba a cierta distancia, con la reata tirante, y miraba al poste haciendo un gesto como de uno que lee un anuncio de lejos; fue acercándose poco a poco, hasta dejar al colgado a una altura razonable. Le cortaron el pedazo de reata. Se fueron llevándose la polvareda en las pezuñas de sus caballos. Mamá no dijo nada, pero ya no comió la sandía. El asiento de 
adelante quedó vacío; el hombre de la mano en la ventanilla estaba ahorcado enfrente del tren, a diez metros de distancia... . (p. 122)

El simple gesto de no comer más sandía hace patente en el adulto la reacción a los hechos violentos. No así en la niña: como emisor, se limita a registrar el hecho, frente al pasaje de un tren (símbolo ambivalente de la misma Revolución). Este distanciamiento, entonces, pone énfasis en una mirada que reconduce al referente dentro de un marco consuetudinario, lo encasilla como normal en la rutina del juego de la vida y de la guerra. No se trata, sin embargo, de una incomprensión de la "realidad": no hay signos del trauma, ni ruptura de la rutina porque la narración expone lo que es ya una nueva rutina (Sartre, 2015).

La voz del sujeto se desplaza y ofrece, desde la ingenuidad de su alteridad, un relato alternativo de la Revolución y así sus palabras "tienen la crueldad lacónica de la infancia" (Poniatowska, 2006, p. 171). Relata lo que ve y lo que escucha: oídos y ojos de niña. La narradora de Cartucho muestra, así, una clara percepción de la guerra y de sus consecuencias, pero las emociones y los deseos de la niña aparecen como estancados sobre una nota fija, sin intensidad. Pareciera haber en la protagonista una ataraxia de los sentidos: sobresale sólo el deseo de continuidad temporal y experiencial con el objeto de la mirada. Así, el punto de vista de la niña comparte la vía de acceso a la observación del referente, pero también sus limitaciones: al no ser omnisciente, la narración limita lo asible del fenómeno a lo "visible" y a lo "experimentable" a partir de una específica corporeidad infantil y de su sentir.

En el fragmento "Desde una ventana", que desde el título reafirma la centralidad de la perspectiva visual y de distanciamiento en la novela, se puede leer:

Como estuvo tres noches tirado, ya me había acostumbrado a ver el garabato de su cuerpo, caído hacia su izquierda con las manos en la cara, durmiendo allí, junto de mí. Me parecía mío aquel muerto. Había momentos que, temerosa de que se lo hubieran llevado, me levantaba corriendo y me trepaba en la ventana; era mi obsesión en las noches, me gustaba verlo porque me parecía que tenía mucho miedo.

Un día, después de comer, me fui corriendo para contemplarlo desde la ventana, ya no estaba. El muerto tímido había sido robado por alguien, la tierra se quedó dibujada y sola. Me dormí aquel día soñando en que fusilarían otro y deseando que fuera junto a mi casa. (Campobello, 2017, p. 123)

La impasibilidad del personaje infantil frente a un cuerpo sin vida, frente a la muerte, crea virtualmente, en la recepción del lector, cierto malestar: hay un corto circuito lógico respecto a lo que la emoción socialmente construida prevé (Ahmed, 2015). Instaurando un diálogo imposible con la muerte, al contrario, el cadáver frente a la ventana crea en la niña un vínculo emocional allá donde, en apariencia, no había emociones y donde nos esperaríamos -como lectores-adultos- una reacción de miedo o de repulsión. En cambio, en una aporía semántica, es el cuerpo sin vida el que expresa emociones de timidez y de miedo (dilación de aquellas emociones que caracterizaron sus últimos suspiros). Hay entonces un acostumbrarse a la mirada de la muerte que crea una paradoja entre un apego emocional y una necesidad relacional que se manifiesta en el sueño deseante de otro fusilado próximo a la vista. 
Según la definición de Sartre (2015), la emoción es la reacción -inconsciente y "mágica"- de un cuerpo frente a una transformación del mundo (exterior al cuerpo mismo) y a la tensión que el cambio produce (sin que ésta pueda ser aprendida por el sujeto). La emoción, entonces, para Sartre,

Es una transformación del mundo. Cuando los caminos trazados se hacen demasiado difíciles o cuando no vislumbramos caminos, ya no podemos permanecer en un mundo tan urgente y difícil. Todas las vías están cortadas y, sin embargo, hay que actuar. Tratamos entonces de cambiar el mundo, o sea, de vivirlo como si la relación entre las cosas y sus potencialidades no estuvieran regidas por unos procesos deterministas sino mágicamente. No se trata de un juego, entendámoslo bien; nos vemos obligados a ello y nos lanzamos hacia esa nueva actitud con toda la fuerza de que disponemos. Lo que hay que comprender también es que ese intento no es consciente como tal, pues sería entonces objeto de una reflexión. (pp. 69-70)

Asimismo, en Cartucho, frente a la manifestación de la muerte en las calles de Parral o en la liminalidad del hogar, no hay transformación, no hay por parte del cuerpo de la niña ninguna necesidad de "conjurar" la realidad. La muerte es ya parte de la significación cotidiana del entorno íntimo de la guerra civil, sobre todo por quien ha visto coincidir en sincronía la propia experiencia vital con esa guerra. Por paradójico que parezca, la emoción sobreviene sólo frente a la epifanía negativa del cadáver desaparecido.

La misma ventana filtra la observación de un episodio similar y casi contiguo en la estructura narrativa, en el fragmento "El muerto". Pero esta vez la madre, ausente en la escena, intenta ejercer una función protectora y de censora frente a una manifestación concreta y estética de la guerra justo frente a la casa: "El caso es que las balas pasaban por la mera puerta, a mí me pareció muy bonito" (Campobello, 2017, p. 116). Pero la niña y su hermana eluden el control y se suben a una ventana ansiosas de encontrar con la vista algún cadáver tirado en la calle y, frustrada la espera, la voz de la niña enuncia toda su decepción: "Buscamos y no había ni un solo muerto, lo sentimos de veras" (p. 116). Luego, finalmente, se cumple la promesa del título con la muerte de un soldado carrancista. Sin embargo, el valor determinativo del artículo en el título resulta engañoso: "el" muerto es en realidad "un" muerto, uno más que deja su rastro en la calle. Lo conocido que ese artículo implica, entonces, señala a lo ordinario de la muerte en el contexto referencial de la guerra y no a la especificidad del episodio narrado. Por lo dicho, es evidente que no hay aquí alguna participación emotiva: como explica Josebe Martínez (2019), "Campobello salta todas las censuras impuestas a la mirada para hacer visible lo intolerable, para mostrar el horror sin el recurso a la lágrima” (p. 56).

Ese mundo es, para la niña, el único mundo conocido y la proximidad de la muerte lo permea, hasta el punto que es posible "leer" la aparición de los soldados como fantasmal, como prefiguración de un desenlace ciertamente cercano y fatal: "A pesar de todo, aquel fusilado no era un vivo, el hombre mocho que pasó frente a la casa ya estaba muerto" (p. 117). La niña no expresa sentimientos, pero reconoce el sentir que trasluce en la corporeidad de los demás a su alrededor y lo visibiliza: nota, por ejemplo, el temblor en la mano y en los ojos de Martín López que "adormecido de dolor recitaba una historia dorada de balas" (Campobello, 2017, p. 136).

Esta clave emocional átona de la niña es confirmada por el contraste con la actitud del mundo adulto frente a la muerte. Los sentimientos no están ausentes, ni "deshumanizados" (como, al contrario, sostiene Estévez, 2014). Pero, como premisa necesaria, para manifestarse dentro del discurso narrativo requieren 
la existencia de un vínculo personal y de una intimidad con el otro que justifique la "trasformación del mundo", en el sentido comentado por Sartre (2015). Vemos, por ejemplo, la reacción radical de Chagua tras la muerte del Kirilí, su enamorado: "se vistió de luto, y poco tiempo después se hizo mujer de la calle" (Campobello, 2017, p. 101). En otros casos, se destaca una emoción que surge del disgusto moral en el marco social de la militancia común: el Peet declara su tristeza frente a la avidez de los villistas al despojar de sus anillos y de su ropa al cuerpo fusilado "todavía calientito" del chofer de Fierro (p. 127); la madre de la niña, por otro lado, juega el papel de un constante contrapeso moral y empático: "Cuentos para mí, que no olvidé. Mamá lo tenía en su corazón” (p. 130).

Por esta razón, no hay que confundir con apatía la aparente indiferencia de la niña frente a la muerte: esta indiferencia retrata al contexto, no al sujeto que lo observa. La niña no carece de sensibilidad, sino de una experiencia más humana, ajena a la guerra. Lo vemos cuando hay con el otro una cercanía que instaura en la niña un vínculo más íntimo: la guerra amenaza en ese entonces el valor de la relación con este otro y genera internamente un temor o un dolor que el sujeto vive a través de su "propia ventana" (Nussbaum, 2008, p. 50). En el caso de Rafael, por ejemplo, la muerte deja en su voz la marca identitaria de una emoción, enunciación directa de tristeza: "Me quedé sin voz, con los ojos abiertos, sufrí tanto, se lo llevaban, tenía unos balazos, vi su pantalón, hoy sí era el de un muerto" (Campobello, 2017, p. 107). Rafael era su amigo - relata- porque un día sus sonrisas fueron iguales, pero su aparición sin vida sobre una camilla rompe traumáticamente la linealidad neutral de la vida en tiempos de guerra. La amistad quiebra esa linealidad de la muerte violenta de manera simbólica ya que, tras la muerte de Zafiro y Zequiel, la niña rompe la jeringa que con ellos usaba para jugar, echándoles chorros de agua. $\mathrm{Y}$ hasta el tono poético de la narración, en ocasiones, deja divisar el sentimiento que la voz modula. De la misma forma, la niña se pone "retriste" cuando Babis, el amigo vendedor de dulces, le comunica que se alistará. La tristeza aparece porque esa noticia prefigura la angustia como sentencia de muerte para Babis: "Pero te van a matar. Tu cara lo dice" (p. 115)

Es interesante observar cómo esta tristeza no surge por la separación, es decir, por el alejarse del sujeto-otro, dado que esto representa una dinámica natural en el contexto de la guerra: la niña sufre la ratificación definitiva, tras la muerte, de esta separación. El sujeto conoce así un cambio en la percepción propioceptiva del otro: la muerte de este otro, introyectado y asumido como amigo, como cercano, va más allá de su mismidad y apela a la ipseidad del sujeto (Ricoeur, 2006), expresando una pasionalidad otras veces ausente en una voz saturada por la fenomenología social y existencial de la guerra. Este mundo interior de la niña-narradora, entonces, muestra la sensibilidad activa del personaje, y no sólo eso: se vuelve "informador" y participa de la significación.

La niña, aquí, representa entonces un enlace visual, verbal y emocional. Da unidad a la representación de la guerra, de su escenario y de sus actores. En ella y en su enunciación se encuentra el principio y el final de la trama: la guerra civil está fuera de su control, pero en sus manos está la madeja de lo narrado y de las relaciones que los personajes tejen. De aquí que la escala de observación de la Revolución encuentre su eje de focalización en la niña y todo movimiento bélico se resume en la cartografía emocional de Parral y, en particular, de una ventana en la Segunda del Rayo. La presencia de la protagonista se

5- Recuperando la propuesta de Greimas y Fontanille (2017), esta tensión emotiva en Cartucho puede traducirse semióticamente en la imposibilidad de prolongar en el tiempo estas relaciones humanas frente al desenlace que la guerra impone: [querer tener + no poder tener (más) $\rightarrow$ tristeza]. 
caracteriza por una constante liminalidad. Se ubica escénicamente en los umbrales, en la proximidad de la puerta o de la ventana, ocupando el espacio vivencial que interconecta lo íntimo de lo doméstico con el espacio exterior de la ciudadanía y de la guerra. Y, además, se ubica también en los umbrales de la percepción, como testigo directo o indirecto de todo acontecimiento, de su sentir y de su relato, dado su estatus de niña que tiñe y caracteriza sus lecturas epistemológicas. De ahí narra, consciente de la importancia de sus palabras y consciente que estas pueden "incrustarse en el pecho, como si fueran plomo" (Campobello, 2017, p. 145). Está presente, observa y escucha, luego narra. Es esta su misión, por eso la autora apenas describe a la protagonista marcándola como sujeto no adulto: "Cartucho no trata de ofrecer el extraño retrato de una niña sobre la pira de los muertos que habitan su memoria, sino la movilidad de esa pira vista y vivida desde dentro" (Faverón-Patriau, 2003, p. 60). Frente a esa "pira" resalta su voz y se refrenda la diégesis inconforme de la Revolución.

\section{El sendero...: la Guerra partisana del niño Pin y su voz}

En un lugar de Italia cuyo nombre el narrador no menciona explícitamente, entre carruggi y hosterías, entre bosques de lárices y bombas que levantan humo al horizonte, vive Pin. Pin es el niño que protagoniza la primera novela de Italo Calvino (1923-1985), El sendero de los nidos de araña, publicada en 1947 por la editorial Einaudi apenas después del final de la Segunda Guerra Mundial. El niño-protagonista encarna el punto de vista de la narración y permite, desde su distanciamiento, la ficcionalización de la experiencia biográfica que Italo Calvino vivió como partisano, con el nombre de batalla de Santiago, en los Alpes Marítimos entre 1943 y 1945 (Barenghi y Falcetto, 2005). Es un niño flaco, con pecas rojas y negras como vuelos de avispas alrededor de los ojos. Pero, antes que nada, es un "grito" que comienza una canción callejera o que intenta zafarse del manotazo de Pietromagro (su segundo padre, putativo, ausente como el primero). Y esa voz no se le seca en la garganta, a pesar de las maldiciones del vecindario, porque es para él la única forma de existir en una realidad que parece admitirlo sólo como eco de presencias ajenas, es decir, como ayudante del zapatero "robagallinas" y como hermano de la Nera de Carruggio Lungo. Irreverente, guiña el ojo a los adultos y a su filosofía del gozo, imitando su risa y a veces su melancolía, como el desencanto de un amor que se consuma en la cama de una prostituta y de un aliento de libertad ahogado en el fondo de un vaso de taberna. Pero Pin es sólo una máscara de groserías y obscenidades: como nos revela la voz externa que rige la narración, en su pecho esconde una densa "niebla" de soledad. Detrás de su voz rebelde, desatinada de niño-viejo, se esconde el continuo deseo de un gesto de aceptación. Esa voz es entonces la que lo define, junto con un abrigo demasiado grande para él.

Como simboliza ese abrigo, el niño-protagonista está suspendido entre dos mundos diferentes, el de la niñez y el de los adultos, pero está al mismo tiempo marginado de los dos. Los otros muchachos no lo quieren por su estar "iniciado" al mundo de los grandes y a su lenguaje: lo rechazan, lo golpean; a veces se le acercan para preguntarle una clave que les permita descifrar algún misterio de los adultos, de su sexualidad sobre todo, pero entonces es Pin quien los rechaza, denigrándolos en el espacio público de la calle. No obstante, también lo rechazan los adultos: "macaco", "feo", "rufián" le gritan de lo alto de las ventanas y él los repaga con la misma moneda, con todo su repertorio verbal de hostería 
y con bromas que dejan un mal sabor de boca: alrededor de él, "gente insieme nemica e amica, gente da scherzarci insieme fino a sfogare quell'odio che ha contro di loro"6 (Calvino, 2005, p. 145).

La aparición en la hostería del misterioso partisano finalmente le ofrece la oportunidad -o mejor dicho el chantaje- de ser reconocido. Se da cuenta, entonces, que aquella misión -seria y misteriosa- lo alejará definitivamente de las risas y de las bromas anteriores: inicia así para el niño un camino de formación que lo llevará lejos del escenario habitual hasta la indagación no consciente sobre la humanidad en tiempos de guerra. Y Pin cumple la misión: roba la pistola del marinero. Pero su primer aprendizaje es la indiferencia de los hombres de la hostería, de aquellos mismos hombres que le encargaron la misión, a partir del pacto que el "misterio" de la palabra gap establecía. La guerra para el niño es un juego "serio" $y$, por esa razón, queda pasmado frente a la falta de interés de los grandes. Es profunda su decepción, enunciada directamente en el texto por la voz narradora: "ormai é sicuro che non dará loro la pistola; ha i lucciconi agli occhi e una rabbia gli stringe le gengive" (p. 21).

Pin reescribe entonces las reglas de aquel "juego"; decide quedarse en secreto la pistola y asegurarla allá donde las arañas hacen su nido, lugar que sólo él conoce. La pistola le permite así, aunque sólo por un momento, hacerse cargo de su construcción identitaria: en una realidad que no lo admite, el objeto le concede, como por arte de magia, una "fuerza terrible" y el respeto de todos, lo cual le permite jugar juegos jamás hechos por niño alguno. ${ }^{9}$ Puede entonces reducir una rana a una baba verde sobre las piedras o hasta matar con un tiro a toda la Tierra. Pero las fantasías lúdicas del protagonista se interrumpen de repente: en el caos de voces no italianas, un farol y el dedo del marinero alemán lo señalan.

Pin, sin embargo, no delata a los hombres de la hostería, afirma que agarró la pistola para dispararle a un gato. Luego, entre los azotes que le hieren la cara, arma un espectáculo de brincos, gritos y corridas para recordarle a quien lo interroga que tiene delante a un sujeto infantil. Por un momento, entonces, desea revelar la ubicación de los nidos de araña y así poder entenderse con los soldados, reírse y beber junto con ellos en la hostería. Pero esto es imposible; continúan golpeándolo y el dolor abruma su irreverencia hasta moldear una posible nueva toma de consciencia:

Piange, invece, un pianto enorme, esagerato, totale come il pianto dei neonati, misto a urli e imprecazioni e a pestate di piedi che lo si sente per tutto il casamento del comando tedesco. Non tradirà Miscèl, Giraffa, l'Autista e gli altri: sono i suoi veri compagni. Pin ora è pieno d’ammirazione per loro perché sono nemici di quelle razze bastarde. Miscèl può star sicuro che Pin non lo tradirà, di là certo sentirà i suoi gridi e dirà: « Un ragazzo di ferro, Pin, resiste e non parla». ${ }^{10}$ (p. 30)

6- (Gente al mismo tiempo enemiga y amiga, gente con la cual bromear juntos hasta desahogar ese odio que tiene en contra de ellos): esta y todas las traducciones del italiano al español presentes en este texto son de mi autoría.

7- Los gap (Grupos de Acción Patriótica) fueron, a partir de la salida de Italia de la Guerra Mundial en 1943, grupos armados activos clandestinamente en las ciudades en contra del ejército de ocupación alemán y de los llamados "repubblichini" (los fascistas de la República de Salò)

8- (ahora está decidido que no les dará a ellos la pistola; tiene llorosos los ojos y la ira le aprieta las encías).

9- En el registro fantástico de la novela, como señala Gabriella Fenocchio (2004), la pistola equivale al objeto mágico de las fábulas y como tal puede permitirle acceder al mundo de los adultos.

10- (Llora, en cambio, un llanto enorme, exagerado, total como el llanto de los neonatos, mezclado a gritos e imprecaciones y a pisadas de pies que se oyen por todo el edificio del mando alemán. No traicionará a Miscèl, Jirafa, el Chofer y a los demás: 
La firmeza de Pin es heroica, sobre todo contrapuesta a la "cara de niño" del oficial que lo golpea y al cambio de bando de Miscèl. Pero la suya no es una firmeza que nace de un ideal, sino de un íntimo deseo de compañerismo: toma sus propias decisiones, pero sometiéndose emotivamente a las reglas de los demás. De aquí que cuando Lupo Rosso (Lobo Rojo) lo llama "compagno" (compañero), independientemente del sentido político socialista o comunista del apelativo, se crean las premisas para que Pin pueda abrirse a una nueva experiencia: "T'hanno conciato bene, compagno"11 (p. 34). Lupo Rosso es un muchacho, un partisano de 16 años cuyo nombre es ya conocido en el pueblo. Frente a él, en su entendimiento parcial de la situación, Pin rellena con la imaginación los datos faltantes: presume el robo de la pistola y se dice parte del gap a cargo de un personaje ficticio, Comitato (Comisión). Este contacto entre presos, en una atmósfera casi de ensueño, lo hace sentir aceptado y le hace desear seguirlo, unirse a una banda de rebeldes partisanos, aunque se sienta tratado como niño:

Dapprincipio, per la questione della pistola rubata, sembrava che con Lupo Rosso si potesse diventare amici sul serio. Ma poi ha continuato a trattarlo come un bambino, e questo da ai nervi. Con gli altri ragazzi di quella età, Pin può almeno far valere la sua superiorità parlando di come son fatte le donne, ma con Lupo Rosso quest'argomento non attacca. Pure sarebbe bello andare in banda con Lupo Rosso e fare grandi esplosioni per fare crollare i ponti, e scendere in città sparando raffiche contro le pattuglie. Forse più bello ancora che la brigata nera. Soltanto la brigata nera ha le teste da morto che sono molto più d'effetto delle stelle tricolori. ${ }^{12}$ (p. 38)

El uniforme es una máscara: tras ella, como recuerda Bajtín (2003), se suceden todos los múltiples aspectos del sujeto, en contraste con la imposible estaticidad del significado único. Y como máscara es intercambiable: un momento antes había soñado con vestir el uniforme de la Brigada negra y disfrutar de su carga de poder y miedo (inscrita en la cabeza de muerto de su gorro); ahora sueña con el bando opuesto (igualmente seductor, aunque menos escenográfico). Son las circunstancias y, sobre todo, la esperanza de una amistad que encaminan a Pin a la vía de los montes, hacia los partisanos, es decir, como conducta mágica e "impaciente" que intenta conjurar la posesión de un objeto (Sartre, 2015). Sin embargo, no será Lupo Rosso quien lo conducirá allá. Después de la rocambolesca fuga de la villa-cárcel, los dos se pierden de vista. Pin llegará a las montañas de los partisanos de la mano de Cugino (Primo) sólo después de transitar por una estratificación imaginativa que trasfigura los senderos conocidos bajo la luz del cuento de hadas.

En el destacamento del Dritto (Derecho) a Pin se le hacen pocas preguntas. Es ahora el ayudante del cocinero Mancino (Zurdo) y -como dice el mismo comandante, confirmando su condición marginal

\footnotetext{
son ellos sus verdaderos compañeros. Pin ahora está lleno de admiración para ellos porque son enemigos de aquellas razas bastardas. Miscèl puede estar seguro que Pin no lo traicionará, del otro lado seguro oirá sus gritos y dirá: «Un hombrecito de hierro, Pin, resiste y no habla»).

11- (Te han puesto una buena, compañero).

12- (En un principio, por el asunto de la pistola robada, parecía que con Lobo Rojo podía volverse amigo de verdad. Pero luego siguió tratándolo como a un niño, y esto saca de quicio. Con sus pares, Pin por lo menos puede demostrar su superioridad hablando de cómo las mujeres están hechas, pero con Lobo Rojo este tema no funciona. Y aun así estaría bien hacer equipo con Lobo Rojo y hacer grandes explosiones para derrumbar los puentes, y bajar a la ciudad descargando ráfagas en contra de las patrullas. Quizás hasta más bárbaro que la misma brigada negra. Sólo la brigada negra tiene las cabezas de muerto que surten mucho más efecto que las estrellas tricolores).
} 
respecto al espacio de la batalla- sus armas serán el cuchillo para las papas y el cucharón. En este escenario, Pin reconfigura su cotidianidad en un espacio social no muy distinto del espacio de la hostería, con sus cantos y sus bromas pesadas. Los hombres del grupo le fascinan y, una vez más, busca su aceptación imitando sus actitudes y pensamientos:

In mezzo ai compagni vuol convincersi d'essere uno come loro, e allora comincia a raccontare cosa farà la volta che lo lasceranno andare in battaglia e si mette a fare il verso della mitragliatrice tenendo i pugni avvicinati sotto gli occhi come sparasse ${ }^{13}$ (Calvino, 2005, p. 75).

Pero la vida de los partisanos, lejos de aquellas montañas y de aquel refugio, significa matar a otros hombres. Los mismos compañeros, en broma, lo alientan a lanzarse a la batalla o a recuperar su secreta P-38. Entonces, en su juego de imaginación, llega a matar a los fascistas, motivándose con el recuerdo de la violencia y de la ofensa recibida. Este deseo de matar -como enuncia la voz narradora- es para él mismo incomprensible, remoto y desagradable, pero excitante "come il fumo e il vino, una voglia che non si capisce bene perché tutti gli uomini labbiano, e che deve racchiudere, a soddisfarla, piaceri segreti e misteriosi"14 (p.75).

Y cuando llega el momento fatídico de abrazar las armas, para defenderse de los fascistas que suben a las montañas guiados por las instrucciones traidoras de Pelle (Piel), Pin vacila por un sentir contrastante. La guerra lo espanta, pero se siente llamado a ser parte de ella, tanto que acaba estorbando los preparativos de los grandes. Ignorado, se llena de enojo y agarra un fusil. Pero, finalmente, queda al margen de los hombres que, en silencio, se alejan en filas. Así, al cobrar una realidad concreta, el manifestarse de la guerra trae consigo el miedo y esto lo vuelve a alejar del mundo adulto, tanto que el mismo espacio a su alrededor pierde su carácter idílico y se vuelve perturbador: "È un giorno azzurro come gli altri, che fa paura vederlo così azzurro, un giorno con canti d'uccelli, che fa paura sentirli cantare”15 (p. 126). Y el miedo del sujeto infantil crece cuando, tras una eternidad de silencio, la batalla explota indefinidamente cercana: "Fragori orribili squarciano l'aria: vicini, sono vicini a lui, non si capisce dove. Tra poco proiettili di fuoco cascheranno su di lui. Tra poco dal giro dei costoni sbucheranno i tedeschi, irti di mitraglie, piomberanno su di lui"16 (p. 133).

Más tarde, el regreso en retirada de la banda produce en Pin un cambio de estado de ánimo que la voz narradora enuncia de forma explícita: Pin está triste. Sentado bajo el sol mientras se quita la mugre de los pies, la noticia de la muerte de Giacinto lo anima a una reflexión que llama en causa a los piojos como metáfora hilada de la caducidad de la vida: "Ma cosa serve togliersi i pidocchi se poi come Giacinto, un giorno si muore? Forse Giacinto non se li toglieva perché sapeva di dover morire"17 (p. 143). Y la tristeza se vuelve

13- (Entre sus compañeros quiere convencerse de ser uno de ellos, y entonces empieza a contar lo que hará esa vez que lo dejarán ir a la batalla y se pone a hacer el sonido de la ametralladora con los puños juntos bajo los ojos como si disparara).

14- (Como el fumar y el vino, un deseo que no se entiende por qué todos los hombres lo tienen, y debe tener, una vez satisfecho, placeres secretos y misteriosos).

15- (Es un día azul como los demás, tanto que da miedo verlo tan azul, un día con cantos de pájaros, que da miedo oírlos cantar).

16- (Fragores horribles desgarran el aire: cerca, están cerca de él, no se entiende dónde. En un rato, balas de fuego le caerán encima. En un rato, detrás de la loma aparecerán los alemanes, llenos de metralletas, saltarán sobre él).

17- (¿Para qué sirve quitarse los piojos si luego como Giacinto, un día se muere? Tal vez Giacinto no se los quitaba porque sabía que le tocaba morirse). 
nostalgia sobre el hilo imaginario que los piojos recorren, hasta encontrar el recuerdo de Pietromagro en la cárcel y de todos los habitantes del carruggio que -como cuenta Gian l’Autista (el Chofer)- ahora es una ciudad reducida a un fantasma por las bombas y por las deportaciones de las SS (Schutzstaffel).

Sin embargo, esta dimensión emocional del protagonista queda enunciada sólo indirectamente. Es la voz narradora y externa que hace inteligible el sentir del niño y sus significaciones para el narratario. La voz de Pin borra siempre los rastros de su mundo interior, dejando prevalecer su papel de testigo irreverente, casi bufonesco, frente a la audiencia amiga-enemiga de los adultos. Así que Pin se excita, su sonrisa deja ver hasta las encías y habla "con ironia compunta, velenosa"18 (145), con un humor cómico (y a veces negro) que causa las risas fragorosas de los demás. Así, enterándose que el destacamento del Dritto será disuelto, Pin da la noticia cómicamente, reasignando con afán burlón a cada hombre como jefe de un destacamento "profano" y a su medida:

- Ma non lo sapete che ci fanno un distaccamento apposta per ciascuno? - dice Pin. - Tutti comandanti, ci fanno. A Berretta-di-Legno lo fanno comandante dei partigiani in poltrona. Sicuro, un reparto di partigiani che fanno le azioni stando seduti. Non ci sono i soldati a cavallo? Adesso fanno i partigiani sulle poltrone a rotelle!

... - Carabiniere! - fa Pin. A ogni nome nuovo tirato in ballo, gli uomini hanno sogghigni sommessi, pregustando già quel che Pin andrà a tirar fuori.

- A Carabiniere daranno un distaccamento speciale... - dice Pin.

- Servizio d’ordine, - dice Carabiniere per mettere le mani avanti.

- No, bello, un distaccamento per prendere i genitori!

... - Indovina che distaccamento comanderai tu, Mancino...

... Pin ha preso quella sua espressione buffonescamente ipocrita, parla lento, untuoso:

- Vedi, il tuo distaccamento sarà un distaccamento quasi come gli altri. Solo potrà andare soltanto per i prati, per le strade larghe, per le pianure coltivate a piante basse... . ${ }^{19}$ (pp. 144-147)

La voz de Pin, sin embargo, es interrumpida, reprimida con violencia. Su juego esta vez deja de ser divertido para el Dritto. La represión rompe la posibilidad del diálogo entre diferentes voces y da paso al desenlace de la experiencia del niño: no le queda más que alejarse, huir del mundo de los adultos, de los partisanos, de su tejido de palabras. El nuevo giro narrativo confirma que la voz de Pin tiene una legitimidad sólo aparente, así como sus acciones en un contexto de guerra: como le recuerda Zena il Lungo (el Largo), es nada más

18- (con ironía compungida, venenosa).

19- (- ¿Qué no saben que nos harán un destacamento personal para cada uno de nosotros? - dice Pin.

- Todos comandantes, nos harán. A Gorra-de-Madera lo harán comandante de los partisanos en sofá. Seguro, un reparto de partisanos que sentados hacen acciones. ¿Acaso no existen ya soldados a caballo? ¡Ahora hacen los partisanos sobre sofá de rueda!

... - ¡Carabinero! - dice Pin. Con cada nombre sacado a relucir, los hombres muestran sonrisas maliciosas, oliendo ya lo que Pin sacaría.

- A Carabinero le darán un destacamento especial... - dice Pin.

- Servicio de orden, - dice Carabinero para prevenir el golpe.

- No, amigo, jun destacamento para atrapar a los padres de familia!

... - ¿Adivina que destacamento comandarás tú, Zurdo...?

... Pin esa expresión suya bufonesca e hipócrita, habla lento, escurridizo:

- Mira, tu destacamento será un destacamento casi igual a los demás. Pero sólo podrá andar por los pastizales, por las calles anchas, por las llanuras cultivadas con plantas bajas... . 
que un muchacho, no le hacen caso. De aquí que un niño puede aportar sólo indirectamente, de reflejo, a la significación del pasado. A pesar de su relativa cercanía con el mundo adulto, queda excluido de esto y de su ciudadanía: así que, desde un punto de vista epistémico, esta alteridad se modaliza en la constante oscilación del juicio sobre la amistad o la no amistad del otro. Por esta razón, la voz de Pin necesita, aléticamente, de la voz heterodiegética de un narrador externo y casi omnisciente. O de otra voz intradiegética, pero "autorizada", como la del comisario Kim. En esta pluralidad, recuperando la perspectiva de Bajtín, se cruzan mundos y consciencias diferentes, frente a un referente único (pero no monolítico): "la variación del tema en muchas y diversas voces, un polivocalismo y heterovocalismo fundamental e insustituible" (2012, pp. 190-191). Es así creada, en el texto, una polifonía que refleja, tras ese juego de espejos, al autor "real" y su ideología.

\section{Cerezas: la Guerra civil de Aurora y sus voces}

Alegre y llena de energía, la niña sube por el lomo de un árbol familiar en el cual descansan frutos todavía no maduros. Esta niña, que en Cerezas dice "yo", tiene siete años y desafía, traviesa, las prohibiciones de los adultos, en un abrazo constante a su cerezo. Ese árbol, que es su herencia prometida y que conecta la voz adulta del narrador a las vivencias infantiles, ocupa un lugar central en la narración: con su presencia silente marca la continuidad de la vida cotidiana hasta que la guerra llega a manifestarse como "fantasma de nuestras vidas" (Correa, 2008, p. 25).

Cerezas es la novela que Aurora Correa (1930-2008) escribe en la madurez de su exilio mexicano, la cual publica en 2008 bajo el sello del Instituto Cultural de Aguascalientes. La obra reúne los apuntes y las notas mecanoescritas de su infancia, desde la sincronía de la Guerra civil y hasta el viaje a México que la convertirá en uno de los llamados "niños de Morelia" ${ }^{20}$. En la narración de la niña, la guerra aparece imponiendo su presencia con alarmas que quebrantan lo cotidiano y convierten escuelas en refugio. Pero, sobre todo, la presencia del conflicto acarrea nuevas significaciones en la voz de todos los actores presentes. Emblemático, en este sentido, es el episodio en sí trivial que convierte transitoriamente a la niña en heroína de guerra por una herida en la cabeza. Por la complicidad del rol infantil de la víctima, el contexto bélico sugiere la sobreinterpretación del significado de la herida, debido en realidad a un desacuerdo lúdico-violento con su hermano Raúl:

Pero yo era una niña con la cabeza partida y de inmediato me atendió un guapísimo de bigotito, gorra miliciana, bata que había sido blanca y manos como la seda de los gusanos de mi hermana. Me preguntaba qué cómo, qué donde, qué si había visto al que me disparó. Y es que andaban sueltos por toda Barcelona demasiados locos escapados del manicomio del odio y mataban a cualquiera. (p. 20)

20- En 1937, con el precipitar de la Guerra civil española, un grupo de casi 500 niños es enviado a pasar unas vacaciones en México. Bajo la invitación del presidente Lázaro Cárdenas, estos niños viajan a México a bordo del vapor Mexique. Entre estos se encontraba Aurora Correa, con apenas siete años. Sin embargo, el final de la guerra y la derrota del bando republicano convertirán dichas vacaciones en el exilio de toda una vida: "La República nos llamó hijos del pueblo, la prensa mexicana nos bautizó huerfanitos de la guerra, el Presidente Cárdenas nos otorgó el título entrañable de hijos adoptivos de la patria y la vida nos convirtió en los niños de Morelia que es como figuramos y así lo registraron los libros de historia ...." (Correa, 2008, p. 244). Aurora Correa traduce en literatura esta experiencia en dos novelas autobiográficas: Te beso buenas noches (1997) y Cerezas (2008). 
La guerra civil — lo deja claro la afirmación del médico— no se detiene por nadie, ni por una niña La cabeza vendada la inscribe simbólicamente como participante activa de la guerra (“¿Verdad que eres miliciana y no sientes el dolor de las puntadas?", p. 20) y le permite ver en primera persona el gran número de heridos del bando republicano para dejar de eso un testimonio, a través de una enunciación adulta que "elabora" (LaCapra, 2005) y que, en el presente de la escritura, viste un disfraz infantil: "Mis desmayos fue mi participación en la guerra, no por la sangre de bala que no me hirió, sino por ver la sangre de los milicianos, mutilados y muertos por los fascistas" (Correa, 2008, p. 20).

Esta voz, en cambio, muestra una naturaleza en esencia infantil cuando declara no comprender las reacciones de los padres o cuando inventa nuevos juegos inspirándose en los cambios evidentes en una realidad y en un escenario que la supera. Al mismo tiempo, intenta dialogar con las otras voces adultas: la niña recuerda, por ejemplo, el descubrimiento de un erizo entre los escombros de un edificio (mientras los adultos intentan ayudar con piedras y palos), o cómo el señor Jordi Sanfeliú, su vecino, decide eliminar el "san" de su apellido para no suscitar las sospechas de los republicanos. Asimismo, un espacio traumático, como lo puede ser un hospital para un sujeto infantil herido, se vuelve la oportunidad de una experiencia iniciática que le da acceso al hermético mundo adulto: "Fue sensacional al otro día narrar a mis amiguitas cómo descubrí el origen de la alarma que anunciaba los bombardeos y ordenaba ir al refugio, y fui la heroína gracias a mi cabeza vendada” (p. 21).

Esta etapa "iniciática" y de descubrimiento coincide, para la niña, con el comienzo de la escuela (pronto convertida en refugio por las necesidades bélicas). Así, en su primer aprendizaje, Aurora encuentra palabras que le resultan enigmáticas porque pertenecen al léxico de los adultos o de la guerra. “QQué es genes?” o “QQué es antiaéreo?” pregunta la niña en su papel de alumna: "Explicarlo no era lo mismo que ver esta palabra enfundada en un cañón dirigido a los bombarderos alemanes, colocado en la escuela Pablo Iglesias ... " (p. 45). En este marco, el verdadero aprendizaje está en aquellos cuentos que vienen de las calles en guerra, del soliloquio de los edificios derribados, de la voz de familiares y amigos, como "búsqueda de las palabras apropiadas, del registro justo y del tono mismo con los cuales hablar de la experiencia de la violencia” (Jimeno, 2008, p. 264). Aprender las "cuentas”, en cambio, resulta más difícil frente a improbables ábacos de cadáveres: “¿Cuántos eran? ¡Quién sabe! No hay maestros que puedan enseñar aritmética con fusilados descubiertos de repente en un monte dorado de Barcelona" (Correa, 2008, p. 89).

Hay entonces, en Cerezas, una voz situada que pareciera coincidir con la voz narradora, como "pacto autobiográfico" (Lejeune, 1991) que anula la distancia entre el lugar de la enunciación y el lugar del enunciado, pero es una voz que el desplazamiento de la memoria hace igualmente ficcional: en el desajuste entre el yo adulto que narra y el yo del niño que fue, la voz de esa niña es un sí mismo, pero también un otro (Ricoeur, 2006).

Como sujeto "recordado", la voz de la niña se alterna entonces a "las voces de la muerte" (Correa, 2008, p. 17) que resuenan en su niñez catalana, antes del exilio, en una enunciación que pone en un diálogo intermitente los datos subjetivos de la "realidad" conocida con las ficciones de la novela y de la historia oficial (Kermode, 2004). En este diálogo, sin embargo, la dimensión autobiográfica y memorial de la escritura hace que la visión adulta y a posteriori de los eventos compita con la significación del punto de vista infantil coevo al tiempo sincrónico de la narración. Esta alternancia entre la enunciación infantil y la enunciación adulta, a veces, se da en el espacio contiguo entre dos líneas del texto: 
¿Quién inventaría el mercado negro? ¿Por qué negro y no rojo o morado, colores que parecían haber sustituido los amarillos y rojos catalanes?

La guerra instaló el mercado negro en mi barrio con sus crótalos de codicias y delaciones. (Correa, 2008, p. 122)

En esta alternancia, la voz adulta trasfigura con connotaciones figurativas y morales el lenguaje infantil y su curiosidad característica, marcando la distancia efectiva y la interferencia entre los dos sujetos.

Aurora, como narradora adulta, autoconsciente, enuncia desde las "Luces de otros años" (p. 22), entre "Runrunes de verdad y fantasía" (p. 23), desde la distancia temporal de una memoria que "atropella los recuerdos" (p. 41). Desde el presente del autor "real”, la enunciación declara así la irreversibilidad del tiempo que queda manifiesta en las huellas de vivencias subjetivas ya borradas: "Ya no existe, ni mi calle, ni mi barrio, ni aquella Barcelona mía" (p. 18); "He perdido sus respuestas y las que me invento no me satisfacen" (p. 106). Como narradora adulta, puede modalizar de forma epistémica su enunciación, comprometiéndose con la verdad de su relato (una operación que, por su alteridad, quedaría potencialmente vetada por la niñez del enunciador). Así, por ejemplo, en retrospectiva, atribuye la razón en la disputa entre voces que no concuerdan al atribuir las responsabilidades de un momento del conflicto: "Abuela tenía razón. Si bombardeaban ciudades y estuvieron a punto de borrar del mapa a Madrid ¿qué importancia tenía para ellos una iglesia de Barcelona?” (p. 73).

Esa voz adulta, entonces, puede reflexionar también sobre las esperanzas republicanas de futuro que unían a la gente como sueño de una humanidad renacida y como anticipación en fin de la prosperidad (Marina y López Penas, 2013) o, viceversa, sobre el "trauma colectivo" provocado por la guerra y manifiesto en la corrupción del discurso que involucra amigos y vecinos, arruinando la atmósfera antes amistosa:

Mi madre y las vecinas daban vuelo a la hilacha verbal de todas las mujeres. ¿Cotilleo? Cotilleaban. ¿Insultos? Insultaban. ¿Amenazas? Amenazaban. No se medían y solo paraban cuando la furia grosera se materializaba haciendo añicos la tertulia, y del me cago en dios pasaban a embarrar la mierda en los hocicos de vecinos, amigos, fascistas, militares alzados, curas, monjas y algunos dirigentes republicanos, a los que remataban cargándoles toda la culpa. (Correa, 2008, p. 64)

Del mismo modo, esa voz es adulta cuando en el recuerdo de un día particularmente trágico compara el escenario con una pintura de Goya o Picasso, o cuando parece hacer eco de la metáfora sombría de la "leche negra"21 que Paul Celan usaba para evocar la cotidianidad del lager, dentro del infierno concentracionario: "La buena leche de nuestra vida se agrió y se llenó de huevecillos de moscas azules. Se vivía para la guerra" (Correa, 2008, p. 92). Asimismo juega con diferentes registros, como cuando ironiza sobre la contribución suya y de su hermano "a la grandeza republicana" a través de su tarea de limpiar las conejeras y los gallineros.

Adulta o infantil, la voz rememora las andanzas de un sujeto que intenta conservar su rutina infantil y familiar a pesar de la guerra, saltando cercas, escuchando la radio y, sobre todo, saboreando sus cerezas.

21- En la traducción de Hernán Bravo Varela, Paul Celan (2007) así comienza su poema Todesfuge (Fuga de muerte): “Leche negra del alba la bebemos de tarde / la bebemos de ocaso y de mañana la bebemos de noche / bebemos y bebemos / cavamos una tumba entre los aires allí se yace cómodo". 
Además, el tono familiar de la narración muestra la posibilidad malgastada de una vida que podría haber sido feliz y tranquila, para siempre, si no hubieran aparecido gradualmente - como en los cuentos de hadas - eventos y signos a desencadenar la catástrofe. Esa catástrofe, aquí, es obviamente la presencia fantasmal de la guerra. Ésta la llevará lejos, desplazando su voz en el espacio y en el tiempo hasta volverla plural, resumiendo la fraternidad de quinientas otras voces (hermanas, españolas y exiliadas) que plantean -como diría Judith Butler (2006) - una demanda ética que cautiva al testigo y exige su horizonte discursivo. Es, en fin, una voz melancólica y certera como las coplas de la abuela que la memoria registró.

\section{Conclusión}

Estos niños, como personajes y sujetos, orientan la narración a partir de una "voz" (Filinich, 2013) que no se limita a relatar e informar sobre el referente. Como podemos observar en Nellie Campobello, Italo Calvino y Aurora Correa, en el tablero de la narración, el niño es la pieza clave de la estrategia literaria. A él, a ellas, el autor otorga la misión de visibilizar -más allá de la tramoya retórica- lo "indecible" (Angenot, 2010). En el salto semiótico que su alteridad le permite, el niño revela entonces la naturaleza profunda del conflicto y la índole fratricida de la guerra, sin maniqueísmo, aunque sin equiparar las partes (y las razones) de la lucha. Deja que se vean, tras el velo aglutinador del heroísmo y del discurso patrio, los signos de ideales confusos, de una violencia que se vuelve insensata, de celos y venganzas entre vecinos y ciudadanos. Su voz es entonces llamada a construir una diferente vía de conocimiento, más relacional, impactando discursiva y políticamente como memoria "ejemplar" (Todorov, 2000) de ese pasado. La "realidad" es retratada por distanciamiento, con ojos inusuales, en una imagen indirecta y marcada por "levedad" (Calvino, 2012).

Este distanciamiento no significa indiferencia en el sujeto, ni el desvío de la mirada: es el pase atrás que autoriza una voz alternativa e inquieta que se disocia de lo que usualmente cabe en la mirada y en la voz "autorizada". Incorporada de manera discursiva a la página, la voz del niño produce el encuentro con un referente que se vuelve signo y significado desde esa subjetividad y emotividad situada. En el roce entre observador y observado, entre enunciación y signo, la narración plantea la posibilidad de una experiencia que deja su limitado estatus de intencionalidad (en potencia, ligado al discurso del autor "real") e invita al lector a un acceso más cercano y privilegiado al evento representado. La novela ofrece entonces un "aura" (Malatesta, 2005) que, socavando la representación hegemónica del evento, traza un sendero intelectual y emocional de comprensión y conocimiento.

En los tres autores, la narración de la guerra civil se ubica en particulares coordenadas históricas y memorialistas, pero siempre encuentra su origen en la subjetividad de un niño ficcional. El punto de vista del niño adquiere entonces una densidad espacio-temporal, narratológica y epistémica: una niña desde una ventana, un niño huérfano en las montañas de los partisanos, un yo de la infancia desde la nostalgia del recuerdo. La figura infantil es entonces la clave de acceso a ese "sendero", como subjetividad que vive y describe el mismo mundo de los adultos, pero desarmado de retórica y de experiencia previa. Como un yo lírico inmergido en una realidad de palabras aún no reveladas, ese niño descubre, significa y finalmente rompe su silencio: sus emociones (explícitas o implícitas en la página) vehiculan un discurso que dialoga o lucha con otros discursos, una autoridad "desde abajo" que altera la autoridad oficial (y su chan- 
taje de inteligibilidad) sugiriendo la importancia de otras voces. Como el rey de las fábulas antiguas, éste reúne en sus manos la narración y sus reglas: inquieto, reivindica su ciudadanía en un mundo adulto y en una historicidad comprensiva, rechazando su supuesta marginalidad en las cristalizaciones del discurso oficial. Además, como infans (es decir, como sujeto carente de habla), el niño señala las limitaciones del sujeto del discurso y de su testimonio (Calveiro, 2006).

La suya es una voz protagónica, pero no única. En su diálogo se plantea la posibilidad de aprendizaje, con un guiño potencial al género del Bildungsroman (novela de aprendizaje). Pero no siempre es así. No parece haber una gradualidad en el aprendizaje de la niña de Campobello, asentada en una voz que permanece constante, pero jamás indiferente frente a la guerra; para Pin, éste corresponde a una voz que expresa la natural ambivalencia del ser humano, pero sin verdades definitivas, oscilando constantemente entre los polos opuestos de la aceptación y del rechazo, como "storia di un'iniziazione continuamente rinviata"22 (Barenghi, 2009, p. 12); para Aurora, corresponde a la separación forzosa de la infancia en la tierra natal hasta las "vacaciones" lejos de la guerra y de los afectos de ultramar. Además, en Cerezas y, sobre todo, en El Sendero..., es la misma guerra civil que representa, en su conjunto de acciones y gestos, una etapa iniciática de aprendizaje colectivo, cívico, y por eso no reducible a una mitología fundacional.

En este sentido, es esencial la función de extrañamiento que, activada por el sujeto-niño en su enunciación, modaliza aléticamente la particular "verdad" relatada, evocando la sinceridad proverbial de los niños (como la de los ebrios) y, al mismo tiempo, define su disposición emotiva. De esta forma, validando la propuesta de Bajtín, se hace patente la ilegitimidad de cualquier voz que se pretenda única y autoritaria (como la voz oficial de la historia o, en su defecto, la voz adulta): la complejidad del referente requiere una pluralidad dialógica de voces. El narrador externo y omnisciente deja espacio, entonces, a múltiples "focalizaciones" (Genette, 2006) internas e interconectadas. El sujeto-niño, dada su alteridad, es objeto de una construcción literaria que intenta poner en crisis el continuum del discurso social hegemónico, inscribiendo en sí -a través de marcas textuales diseminadas a lo largo de la narración- una subjetividad y una carga emocional específica y kairológica. Así, la niña que en Cartucho dice "yo" reúne las diferentes voces del vecindario (voces femeninas, sobre todo) y las filtra con la suya, voz infantil cuyo único mundo conocido es un mundo en guerra. Pin, con una voz desmitificadora que toma prestadas las palabras de los adultos, media entre las voces heterogéneas frente al evento bélico y la humanidad esencialmente común de sus emisores. Aurora-niña, entre nostalgia e idealización, modula en las frecuencias del recuerdo una voz que describe una humanidad en el acto de inscribirse y ser inscrita en el conflicto.

Frente a la memoria del conflicto y a los conflictos de la memoria, la figura del niño adquiere un sentido también biográfico y, por ende, se vuelve un testigo clave. Porque, como recuerda Paloma Aguilar Fernández, es la generación que vive la guerra durante la niñez la que "recibe la impronta más profunda de esta experiencia” (1996, p. 30). Entonces, en una inversión lógica, como en las fábulas que escenifican la utopía de un "mundo al revés", es ahora la significación del niño que ha de traer enseñanza a los adultos. Como la perspectiva, también las palabras y su valor denotativo se vuelcan y expresan la protesta de un sujeto infantil que sueña con vivir entre una mejor humanidad (esa misma humanidad auspiciada por la vertiente utópica y revolucionaria jamás ausente en los ánimos de los civiles en armas). Frente a un escenario íntimo invadido por la guerra, ese niño-protagonista busca entonces reparo en lo lírico, en lo fabulístico, es decir, 
en una realidad plasmada por la propia interpretación, extraña e infantil, pero no por esa razón falsa.

Las palabras, que el niño como sujeto "ingenuo" enuncia, ponen en evidencia la relevancia del discurso emitido y su alteridad situada y, asimismo, sugieren cuatro potenciales niveles de análisis. Primero, en su iniciación al mundo de la vida, su voz guarda las huellas verbales de los adultos que lo rodean en cuanto expresión autorizada del "discurso social" (Angenot, 1998, 2010). Segundo, la aparente neutralidad, es decir, su falta de prejuicios, permite entrever, bajo la superficie de las palabras, la perspectiva propia del autor sobre el referente. Tercero, al señalar lo parcial y lo limitado de la voz infantil, invita a dar un paso atrás para vislumbrar el fenómeno en su totalidad, compleja y no monológica, así como sus perspectivas discordantes (Bajtín, 1989, 2012). Cuarto, el entramado emocional que emerge de la enunciación subjetiva se encarna en el lenguaje narrativo, a través de recursos textuales lexicales, retóricos y narratológicos (Bermúdez Antúnez, 2010).

Este niño, en la centralidad que adquiere en esta nueva narrativa, puede "rebelarse" y manifestar su punto de vista no alineado: no se deja convencer por la visión del mundo adulto ni por sus tipificaciones identitarias. Pese a ser protagonista, no juega propiamente el papel de héroe, sino que elige sus propios héroes, aunque estos no tengan nombres altisonantes ni grados pomposos: intercambia entonces sonrisas con el joven soldado raso que aparece en su casa para pedir que se le cosan unos botones (Cartucho); se mofa del otro en el intento ingenuo de conectarse de forma íntima y ser reconocido (El sendero...); replica en el juego infantil los cantos y los gestos de los milicianos (Cerezas). Otras subjetividades, las cuales comparten con el niño el escenario, son así invitadas, narrativamente, a construir una visión multíplice del referente, más compleja y más plural.

Así, en la cotidianidad de la realidad bélica, el sujeto-niño busca lo que Bernard Lahire define como "lugar simbólico" (Trevignani y Videgain, 2016), al construir una experiencia intersubjetiva en el encuentro y en el conflicto con el otro. Este otro coincide con las figuras maternas y paternas (naturales o putativas), con los familiares cercanos, con los vecinos, con las diferentes personificaciones del enemigo y, al final, con la muerte que -como en Cartucho- acecha y dibuja "garabatos" de cuerpos a pocos pasos del hogar. En este sentido, la escritura configura la intersubjetividad del testigo infantil a partir de una sintaxis de emociones que co-construye la significación del evento (aunque sin sugerir la reducción de lo emocional a lenguaje). Esta emoción -narrada y enunciada- manifiesta dialógicamente el intento de encontrar una significación para esa "realidad" externa y, al mismo tiempo, interna (como intersección de lo infantil con lo adulto, lo social y lo bélico, lo literario y lo histórico) y, gracias a la literariedad del texto, esas emociones aparecen bajo un orden inteligible y contribuyen a la significación global del texto. Como sujeto entre una pluralidad de otras voces, el niño, puede encontrar finalmente en las emociones "formas de entender el mundo cargadas de valor" (Nussbaum, 2008, p. 112) y, por esta vía, buscar su significado frente a la guerra civil como referente complejo y problemático.

A partir de esta función de la voz, que podemos definir emotiva o expresiva (Jakobson, 1981), el niño señala desde dónde el emisor habla, para quién, en qué momento, con qué autoridad y con qué potencial impacto sobre la comunidad. Entonces, esa voz asegura su distancia respecto a un discurso hegemónico que aparenta describir el acontecimiento de una forma sintética y abarcadora. En cambio, es convocada una pluralidad de otros sujetos que -como en la metáfora implícita en El sendero de los nidos de araña- se anidan entretejiendo una "intertextualidad" como laberíntica telaraña de textos. Pero se trata de un texto "secreto", bien escondido para quien no sepa verlo: frente al discurso dominante, lo que el niño enuncia 
se arriesga a perder su legitimidad y, por consecuencia, a no existir (como probablemente no existen esos nidos de araña, los cuales sólo Pin conoce).

\section{Referencias}

Aguilar Fernández, P. (1996). Memoria y olvido de la Guerra Civil española. Alianza Editorial.

Ahmed, S. (2015). La política cultural de las emociones (C. O. Mansuy, trad.). UNAM.

Angenot, M. (1998). Interdiscursividades. De hegemonías y disidencias (G. Weller, trad.). Editorial Universidad Nacional de Córdoba.

Angenot, M. (2010). El discurso social. Los límites históricos de lo pensable y lo decible (H. H. García, trad.). Siglo XXI Editores.

Avechuco, D. (2017). La Revolución narrada desde los márgenes: representaciones anómicas de la violencia en Cartucho, de Nellie Campobello. Literatura Mexicana, 28(1), 69-98. http://dx.doi.org/10.19130/ iifl.litmex.28.1.2017.977

Bajtín, M. (1989). Teoría y estética de la novela. Trabajos de investigación (H. Kriúkova y V. Cazcarra, trad.). Taurus.

Bajtín, M. (2003). La cultura popular en la Edad Media y en el Renacimiento. El contexto de François Rabelais (J. Forcar y C. Conroy, trad.; 9a ed.). Alianza Editorial.

Bajtín, M. (2012). Estética de la creación verbal (T. Bubnova, trad.; 2. ${ }^{a}$ ed.). Siglo XXI Editores.

Barenghi, M. (2009). Calvino. Profili di storia letteraria. Il Mulino.

Barenghi, M., y Falcetto, B. (2005). Cronologia. En I. Calvino, Il sentiero dei nidi di ragno (23.a ed., pp. 27-56). Mondadori.

Bermúdez Antúnez, S. (2010). Las emociones y la teoría literaria: Un encuentro enriquecedor para la comprensión del texto literario. En-Claves Del Pensamiento, 4(8), 147-167.

Butler, J. (2006). Vida precaria. El poder del duelo y la violencia (F. Rodríguez, trad.). Paidós.

Calveiro, P. (2006). Testimonio y memoria en el relato histórico. Acta Poética, 27(2), 65-86. https://doi. org/10.19130/iifl.ap.2006.2.204

Calvino, I. (2005). Il sentiero dei nidi di ragno (23. ${ }^{\mathrm{a}}$ ed.). Mondadori.

Calvino, I. (2012). Seis propuestas para el próximo milenio (A. Bernández y César Palama, trad; 10. ${ }^{\mathrm{a}}$ ed.). Ediciones Siruela.

Campobello, N. (2017). Obra reunida. Fondo de Cultura Económica.

Campobello, N. (2019). Cartucho. Relatos de la lucha en el Norte de México (J. Martínez, ed.). Cátedra.

Carballo, E. (1994). Protagonistas de la literatura mexicana (4. ${ }^{\mathrm{a}}$ ed.). Editorial Porrua.

Celan, P. (02 de julio de 2020). Fuga de muerte. Letras Libres: https://www.letraslibres.com/mexico-espana/ fuga-muerte

Correa, A. (2008). Cerezas. Instituto Cultural de Aguascalientes.

Estévez, D. (2014). La deshumanización como objeto estético en Cartucho de Nellie Campobello: una aproximación desde la crítica literaria, la historia y la sociología. Tesis de Doctorado. Arizona State University: https://repository.asu.edu/attachments/143469/content/Estevez_asu_0010E_14604.pdf

Faverón-Patriau, G. (2003). La rebelión de la memoria: testimonio y reescritura de la realidad en Cartucho 
de Nellie Campobello. Mester, 1(32), 53-71.

Fenocchio, G. (2004). Italo Calvino. En Il Novecento: 2. Dal neorealismo alla globalizzazione (pp. 139-164). Bruno Mondadori.

Filinich, M. (2013). La voz y la mirada. Teoría y análisis de la enunciación literaria. Plaza Valdés Editores; Benemérita Universidad Autónoma de Puebla.

Genette, G. (2006). Figure III : Discorso del racconto (L. Zecchi, trad.; 2. ${ }^{\text {a }}$ ed.). Einaudi.

Greimas, J. y Fontanille, J. (2017). Semiótica de las pasiones. De los estados de cosas a los estados de ánimo. Siglo XXI Editores; Benemérita Universidad Autónoma de Puebla.

Guillén, C. (1985). Entre lo uno y lo diverso. Introducción a la literatura comparada. Crítica.

Jakobson, R. (1981). Ensayos de lingüística general (J. M. Pujol y J. Cabanes, trad.; 2.a ed.). Seix Barral

Jelin, E. (2002). Los trabajos de la memoria. Siglo XXI Editores; Social Science Research Council.

Jimeno, M. (2008). Lenguaje, subjetividades y experiencia de violencia. En F. A. Ortega (Ed.), Veena Das: Sujetos del dolor, agentes de dignidad (pp. 261-291). Lecturas CES.

Kermode, F. (2004). Il senso della fine. Studi sulla teoria del romanzo. Sansoni.

Koselleck, R., y Gadamer, H.-G. (1997). Historia y hermenéutica (F. Oncina, trad.). PaidósICE Universitat Autònoma de Barcelona.

LaCapra, D. (2005). Escribir la historia, escribir el trauma (E. Marengo, trad.). Ediciones Nueva Visión.

Lejeune, P. (1991). El pacto autobiográfico. Suplementos Anthropos, 29(9), 47-61.

Malatesta, M. (2005). Il romanzo: testimonianza e rappresentazione. Contemporanea, 8(4), 698-703.

Marina, J. A. y López Penas, M. (2013). Diccionario de los sentimientos. Anagrama.

Matthews, I. (1997). Nellie Campobello. La centaura del Norte. Cal y Arena.

Nussbaum, M. C. (2008). Paisajes del pensamiento. La inteligencia de las emociones (A. Maira, trad.). Paidós.

Pitocco, F. (2013). "Storia e letteratura. «Danno» e «utilità» di un rapporto controverso." In Il letterato e lo storico. La letteratura creativa como storia (pp. 50-75). Franco Angeli edizioni.

Poniatowska, E. (2006). Nellie Campobello: la que no tuvo muerte. En Las siete cabritas (4 ${ }^{\mathrm{a}}$ ed., pp.157-191). Ediciones Era.

Portelli, A. (2019). "Storia orale, dialogo, e generi narrativi." In P. Favilli (Ed.), Il letterato e lo storico. La letteratura creativa como storia (6a ed., pp. 75-89). Franco Angeli edizioni.

Ricoeur, P. (2006). Sí mismo como otro (3. a ed.). Siglo XXI Editores.

Sartre, J.-P. (2015). Bosquejo de una teoría de las emociones (M. Acheroff, trad.; 3. ${ }^{\mathrm{a}}$ ed.). Alianza Editorial.

Todorov, T. (1971). Literatura y significación (G. Suérez Gómez, trad.). Editorial Planeta.

Todorov, T. (2000). Los abusos de la memoria. Paidós.

Trevignani, V., y Videgain, K. (2016). Explorando emociones en cuentos escritos por niños sobre la escuela, la familia y el barrio. En M. Ariza (Ed.), Emociones, afectos y sociología: diálogos desde la investigación social y la interdisciplina (pp. 37-68). UNAM, Instituto de Investigaciones Sociales. 